Abstracta Iranica Abstracta Iranica

Revue bibliographique pour le domaine irano-aryen

Volume 30 | 2010

Comptes rendus des publications de 2007

\title{
« Human Rights Gaps and Linkages Among Europe, the Middle East and Iran $»$. International Studies Journal, Vol. 4, N 14, automne 2007, pp. 225-239.
}

\section{Anicée Van Engeland}

\section{(2) OpenEdition}

1 Journals

\section{Édition électronique}

URL : http://journals.openedition.org/abstractairanica/38143

DOI : 10.4000/abstractairanica.38143

ISSN : 1961-960X

Éditeur :

CNRS (UMR 7528 Mondes iraniens et indiens), Éditions de l'IFRI

\section{Édition imprimée}

Date de publication : 8 avril 2010

ISSN : 0240-8910

\section{Référence électronique}

Anicée Van Engeland, « « Human Rights Gaps and Linkages Among Europe, the Middle East and Iran ». International Studies Journal, Vol. 4, N 14, automne 2007, pp. 225-239. », Abstracta Iranica [En ligne], Volume 30 | 2010, document 321, mis en ligne le 08 avril 2010, consulté le 27 septembre 2020. URL : http://journals.openedition.org/abstractairanica/38143; DOI : https://doi.org/10.4000/ abstractairanica.38143

Ce document a été généré automatiquement le 27 septembre 2020.

Tous droits réservés 
« Human Rights Gaps and Linkages Among Europe, the Middle East and Iran ». International Studies Journal, Vol. 4, N 14, automne 2007, pp. 225-239.

\section{Anicée Van Engeland}

L'article analyse l'approche de l'Union européenne des droits de l'homme en Iran: l'argument de l'A. est que l'Union tente de renforcer son influence en Iran en adaptant son approche des droits de l'homme ; mais celle-ci est déficiente car elle ne prend en compte que les intérêts des pays membres. Il est de ce fait difficile pour l'Iran de suivre les lignes de conduite présentées par l'Union au gouvernement iranien.

\section{INDEX}

Thèmes : 13.1. Iran

\section{AUTEURS}

\section{ANICÉE VAN ENGELAND}

European University Institute - Florence 